\section{ABCS}

How to cite this article: Rosa et al. Occupational health network: study of the nurses' work process. ABCS Health Sci. 2021;46:e021228. https://doi.org/10.7322/ abcshs.2020119.1571

Received: Aug 04, 2020

Revised: Nov 25, 2020

Approved: Jan 27, 2021

Corresponding author: Leticia Silveira Cardoso - Universidade Federal do Pampa - Campus Uruguaiana - BR 472 - Km 585 - Caixa Postal 118 - CEP: $97501-970$ Uruguaiana (RS), Brazil -

E-mail: Isc_enf@yahoo.com.br

Declaration of interests: nothing to declare Funding: CNPq 404620/2015-9

This is an open access article distributed under the terms of the Creative Commons Attribution License

(C) 2021 The authors

\title{
Occupational health network: study of the nurses' work process
}

\author{
Liane Silveira da Rosa1, Leticia Silveira Cardoso², Valdecir Zavarese da Costa ${ }^{3}$, \\ Marta Regina Cezar-Vaz ${ }^{1}$ \\ ${ }^{1}$ Programa de Pós-Graduação em Enfermagem, Universidade Federal do Rio Grande (FURG) - \\ Rio Grande (RS), Brazil \\ ${ }^{2}$ Curso de Enfermagem, Universidade Federal do Pampa - (UNIPAMPA) - Uruguaiana (RS), Brazil \\ ${ }^{3}$ Programa de Pós-Graduação em Enfermagem, Universidade Federal de Santa Maria (UFSM) - \\ Santa Maria (RS), Brazil
}

\begin{abstract}
Introduction: Nurses, professionals recognized in the health field for their competence to care, are part of the multiprofessional team of the occupational health network. Therefore, they are inserted in the Reference Centers in Occupational Health, in medium and high complexity services and in the managerial scope of this health area. Objective: To establish the relationship between the elements of the nurses' work process in the occupational health network. Methods: Field research carried out with 43 nurses who work in the occupational health network in the Western Border, Macro South and Central regions of Rio Grande do Sul, Brazil. Results: The qualitative technique and the IRAMUTEQ software were used. The analysis of the data allowed to identify that the nurses' work process develops based on the guidelines of the public health policies of the employee. In addition, it was possible to identify that the elements of the work process of these professionals are directly related and organized to meet the workers' needs. Conclusion: This study demonstrates the relevance of the workforce of professional nurses in the occupational health network. Its performance permeates the field of care, health promotion and prevention of accidents at work and occupational diseases and has respective purposes.
\end{abstract}

Keywords: occupational health; nursing; occupational health nursing; health care.

\section{INTRODUCTION}

Occupational health as a public policy and technical area of the Brazilian Health System SUS (Sistema Único de Saúde) is characterized by advances and challenges. Among them, is the access to health services and to work as a social right and a responsibility of the state, whose execution of employee health actions and protection of environments is linked to SUS, according to the National Law $8.080 / 90^{1}$. This law designates the sharing of responsibilities in the field of occupational health with epidemiological and sanitary surveillance. This is so that health promotion, protection, assistance, recovery, and rehabilitation actions can be developed ${ }^{2}$. This sharing was endorsed by the creation in 2002 of the network RENAST (Rede Nacional de Atenção Integral à Saúde do Trabalhador) for the attention of workers' occupational health. RENAST had the objective of contributing to the consolidation of the SUS principles, organization of the functioning and execution of the actions in all the levels of attention of the network ${ }^{3}$. 
From the perspective of networking, the reference centers CEREST (Centros de Referência em Saúde do Trabalhador) are the main investment of RENAST to achieve its goals and to qualify the attention to occupational health. They are composed of multiprofessional teams that provide technical support to local and regional demands in surveillance, assistance, rehabilitation, education, and management ${ }^{4}$.

Nurses, recognized for their caring competence, are part of the mentioned RENAST multiprofessional teams. Therefore, they are part of CEREST in management or assistance, actively contributing to the realization of curative actions, and the promotion and protection of employees' health ${ }^{5}$. However, the reduced number of these professionals in health services with knowledge and/or training in occupational health is a challenge to be overcome ${ }^{6}$. In addition to the accumulation of attributions to the function occupied $^{7}$, there is a devaluation of professionals in this area due to underfunding ${ }^{8}$. The prevalence of underreporting of diseases to employees' health ${ }^{9}$ or the difficulties with the use of communication technologies and health information ${ }^{6,7}$, among others, are also challenges.

It is believed that the study may provide insights that help in the construction of strategies to overcome the challenges evidenced. This fact justifies the present study, based on the Marxist theory of the work process. The conception in which work is a human activity directed to the transformation of an object into a purpose. Moreover, it is composed of recognized elements, such as the object (what will be transformed), the purpose (what guides the work), the instruments or means (what supports the development of work) and the labor force (who performs the work $)^{10}$. Such elements, when defined and recognized, make it possible to know how work is developed and, consequently, its contribution to society ${ }^{11}$.

Therefore, the objective was to understand the relationship between the elements of the work process of nurses in RENAST.

\section{METHODS}

Analytical field research conducted with 43 nurses linked to RENAST in Rio Grande do Sul, Rio Grande do Sul state, Brazil. The participants represent the population of three regional CERESTs (from 12 centers in the state) and their respective Municipal Occupational Health Surveillance Centers, selected by convenience to compose the sample of this research, as shown in Figure 1.

The inclusion criterion for participants was that they were working during the period of data collection, March to December 2016. The exclusion criteria were that the nurse was not covering time off, vacation, or leave of absence of the nurse responsible for the occupational health area. There were no losses or exclusions in data collection. The participants were predominantly female, 40 nurses (93.02\%), aged between 24 and 59 years. The time of work in the occupational health area ranged from four to 264 months, and eight (18.60\%) nurses had specialization in occupational nursing. Exclusive dedication to occupational health activities is possible for five (11.62\%) nurses.

The technique of recorded in-depth interviews was used, with an average duration of 45 minutes and the application of a semi-structured questionnaire, carried out by appointment by telephone seven days in advance, confirmed 48 to 24 hours before the interview. Data collection occurred in the nurses' work environment during the workday in a private room. The information was transcribed and organized in a database in text files. The questions: What are your work actions, how do you perform your work actions? Give examples, for whom do you do it? With whom do you do it? and, For what do you do it? were transformed into a text corpus, according to the guidelines of the software IRAMUTEQ (Interface de $R$ pour lês Analyses Multidimensionnelles de Textes et de Questionnaires) ${ }^{12}$. Afterwards, they were segmented by means of coding that considered ${ }^{* * * *}{ }^{*}$ _1 to 43 , equivalent to the interview number; ${ }^{*}$ posic_1, the professional category nurse; and *uni_1 or 2, respectively the nurse's link to CEREST or to the Municipal Center for Occupational Health Surveillance.

The processing and qualitative thematic analysis ${ }^{13}$ of the data were performed with IRAMUTEQ software. The Descending Hierarchical Classification (DHC) method was used. DHC establishes a textual classification relative to their vocabularies, dividing the sets based on the frequency of their reduced forms. The outcome is a dendrogram that presents the classes of textual segments that, besides having similar vocabulary among themselves, have different vocabulary from the segments of other classes ${ }^{12}$.

This research involves human beings and complies with Resolution 466/2012 of the Brazilian Health Council ${ }^{14}$. Approval was obtained from the representatives of CEREST and the Research Ethics Committee, CAAE: 50737915.2.1001.5323. The Informed Consent Form was used to explain to the participants the objectives and purposes of the research, to ensure access to information, clarification, and to refuse to participate or answer questions. After the presentation of the risks and benefits of participation, participants were asked to sign, in two copies, the informed consent form.

\section{RESULTS}

IRAMUTEQ identified the following features in the corpus: 43 texts, 112 text segments, 641 distinct words, 3,611 occurrences of words and 535 hapaxes, utilizing $63.46 \%$ of the corpus. After the analysis of the textual features, IRAMUTEQ identified, through the DHC method, six distinct semantic classes in the corpus, arranged in the Dendrogram, according to Figure 2. 
Through the Dendrogram analysis, it was identified that the text corpus was divided into two sub-corpuses. From the first, class 2 was obtained, which deals with the macro purpose of nurses' work (SUS Access). This class originates class 3, which deals with the object of work (Work Accident Situations), which is directly related to class 6 , which deals with the purpose of nurses' work (to promote health and prevent work related accidents/diseases). In the second subcorpus, class 1 was obtained, which refers to some of the nurses' work instruments (training, lectures), which are apprehended and ratified in the relation of class 4, nurses' work actions (home visits/orientation) with class 5, which, like class 3 , highlights the work object (work accident situations).

\section{Purpose and object of work of RENAST nurses}

The purpose of the work visualized in classes 2 and 6 meet the premise of integral attention to workers' health. They highlight

\begin{tabular}{|c|c|c|}
\hline \multicolumn{3}{|c|}{ CEREST - Number of nurses } \\
\hline Western Border - 2 & Macro South - 1 & Central - 1 \\
\hline \multicolumn{3}{|c|}{ Municipal Occupational Health Surveillance Center - Number of nurses } \\
\hline Barra do Quaraí - 1 & Agudo -1 & Aceguá - 1 \\
\hline Manoel Viana - 1 & Cacequi -1 & Amaral Ferrador - 1 \\
\hline Quaraí - 1 & Dilermando de Aguiar - 1 & Arroio do Padre - 1 \\
\hline Rosário do Sul - 1 & Dona Francisca - 1 & Arroio do Padre - 1 \\
\hline São Gabriel - 1 & Faxinal do Soturno - 1 & Capão do Leão - 1 \\
\hline \multirow[t]{12}{*}{ Uruguaiana - 1} & Itaara - 1 & Cristal - 1 \\
\hline & Ivorá - 1 & Dom Pedrito - 1 \\
\hline & Jaguari - 1 & Jaguarão - 1 \\
\hline & Mata - 1 & Morro Redondo - 1 \\
\hline & Nova Palma - 1 & Pedro Osório - 1 \\
\hline & Pinhal Grande - 2 & Pinheiro Machado - 1 \\
\hline & Santa Maria - 1 & Piratini - 1 \\
\hline & São João do Polesine - 1 & Santa Vitória do Palmar - 1 \\
\hline & Silveira Martins - 1 & São José do Norte - 1 \\
\hline & Toropi - 1 & São Lourenço do Sul - 1 \\
\hline & Tupaciretã - 1 & \\
\hline & Unistalda - 1 & \\
\hline \multirow{3}{*}{$2+6$} & Subtotals & \\
\hline & $1+18$ & $1+15$ \\
\hline & Total - 43 Nurses & \\
\hline
\end{tabular}

Figure 1: Research Scenarios and Participants.

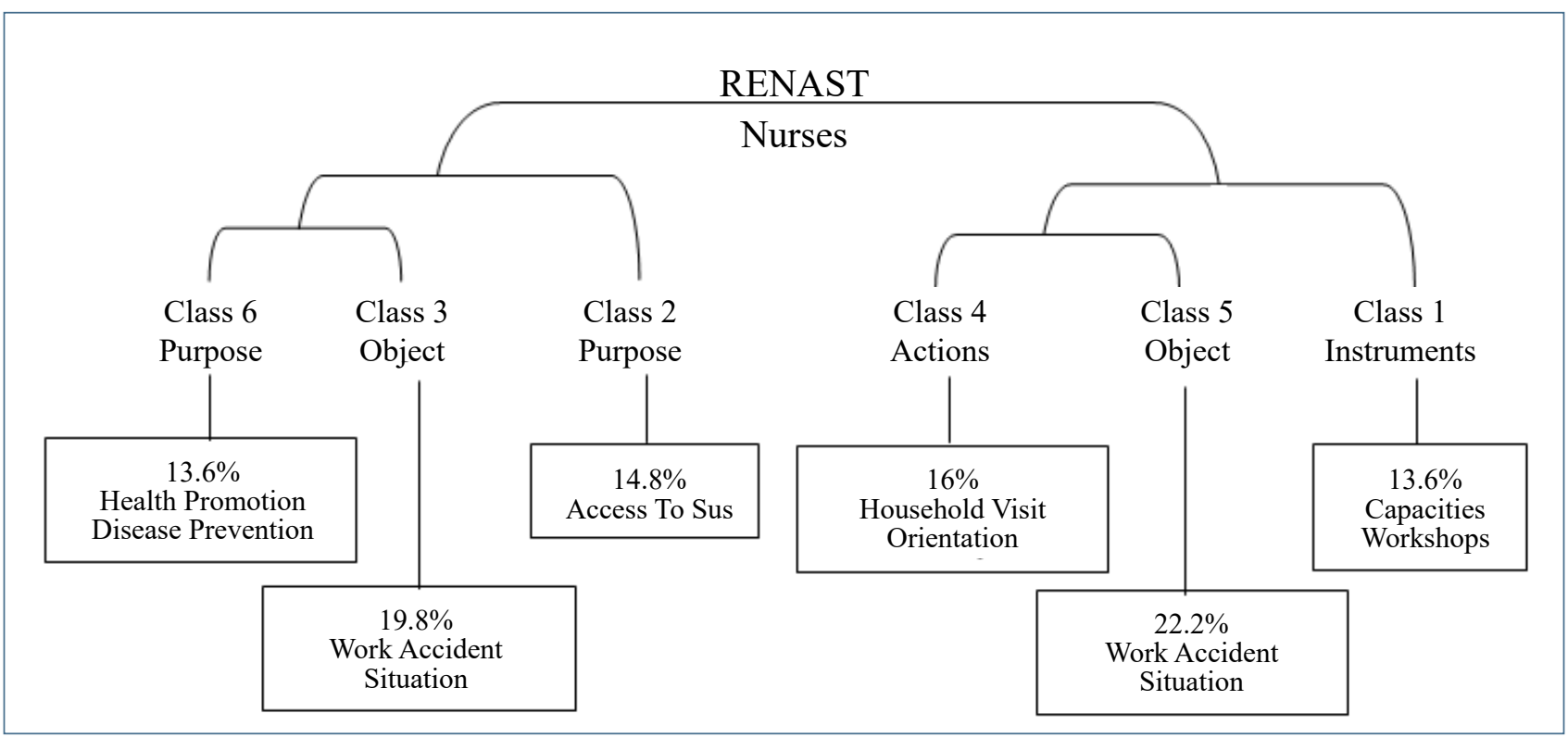

Figure 2: Dendrogram of the classes. Elements of the work process of RENAST nurses from the Western Frontier, Macro South and Central regions of Rio Grande do Sul state, Brazil, 2016. 
the intra-institutional integration between the nurses of CEREST and their respective Municipal Occupational Health Surveillance Centers. The former aim to promote health, prevent occupational diseases and work accidents and, the latter by being located in primary care services work to strengthen and qualify workers' access to health care in SUS. According to the speeches:

(...) the objective of the occupational health actions is to perform health promotion, prevention, to demonstrate to the population the importance of the workers' health to the quality of life $\left({ }^{* * * *}\right.$ n_19* posic_1 ${ }^{*}$ uni_1)

(...) the objective of the occupational health actions is to improve the health and well-being of the working population (**** ${ }^{*}$ __9*posic_1*uni_2)

(...) the goal of the occupational health actions is to provide effective health care as needed $\left({ }^{* * * *} n \_41^{*}\right.$ posic_1 ${ }^{*}$ uni_2)

As the main object of nurses' work, we found, in classes 3 and 5, situations of occupational accidents. These have a broad meaning since they encompass several other objects of nurses' work, such as the worker, the work accident itself, and the work environment. According to the statements:

(...) among my responsibilities is the participation in surveillance actions in work environments $\left({ }^{* * * *} \mathrm{n}_{-} 38^{*}\right.$ posic_1*uni_1)

(...) I follow up workers in rehabilitation and in returning to work, I investigate work-related accidents (...) the objective of the occupational health actions is to minimize illness, work-related accidents, provide well-being, adequate conditions in the work environment $\left({ }^{* * * *} n \_13^{*}\right.$ posic_1*uni_2)

In the relationship between the purpose and the object of work of nurses, it is possible to point out that it is aimed at transforming work-related accident situations by the communality attributed to the object of intervention, which points to the consolidation of the principles of hierarchization and decentralization of SUS. Thus, the congruence between the work environment of the participants, the actions performed, and the function occupied in the RENAST stands out. Since the nurses located in the Municipal Occupational Health Surveillance Centers act as the connection point between CEREST and the various assistance services that make up SUS, in order to safeguard the universality and quality of access to health care by the workers.

\section{Instruments and work actions of RENAST nurses}

The DHC allowed the identification of training and lectures as significant words that made up class 1 and are work tools of
RENAST nurses and work actions performed for external and internal workers of the network. They are carried out in order to broaden the discussion about workers' health, educate workers and instruct health professionals regarding the notifications of occupational accidents. Observe the speeches:

(...) I give educational lectures according to workers' demands and needs $\left({ }^{* * * * *} n_{-} 13^{*}\right.$ posic_1*uni_2)

(...) lecturing in companies, universities, technical courses and for health professionals transmitting information regarding the experience as a CEREST nurse and the surveillance work (**** ${ }^{*}$ __19* ${ }^{*}$ osic_1*uni_1)

(...) I provide training for health professionals to make the notifications of occupational accidents (...) for workers in general about prevention, vaccines $\left({ }^{* * * *} n \_17^{\star}\right.$ posic_l $1^{\star}$ uni_2)

Class 5, like class 3, points to the situation of work-related accidents as the object of work of the investigated nurses. However, the object of work identified in class 5 is different because it encompasses another object of work of the nurses not yet mentioned: the notification of occupational accidents. Observe the statements:

(...) according to the occupational accidents I make the notifications, register in SINAN (Sistema de Informação de Agravos de Notificação), issue RINA $\left({ }^{* * * *}{ }^{*} \_29^{*}\right.$ posic_1*uni_2).

Some instrumental actions of the RENAST nurses' work were pointed out in class 4: home visits and orientation. Home visits are performed in cases of workers who have had an accident or are sick from work and require health care. Orientation, on the other hand, is carried out under two perspectives: the first aimed at orienting workers on their rights, health problems arising from work, and prevention; the second aimed at orienting health professionals who make up RENAST on how to notify work accidents and on the care to be taken in the development of health work. Observe the speeches:

(...) I perform home visits to workers, health follow-up, health referrals $\left({ }^{* * * * *} n_{-} 13^{*}\right.$ posic_1 ${ }^{\star}$ uni_2)

(...) I provide orientation to the workers about health referrals, rights, clarifications about health status and establishing contact with the health department $\left({ }^{* * * *}{ }^{*} \_25^{*}\right.$ posic_1* ${ }^{*}$ uni_2)

(...) I orient workers about the care of the environment, prevention $\left({ }^{* * * *}\right.$ n_37*posic_1 ${ }^{*}$ uni_2)

(...) I instruct the nursing technicians on how to fill out the notifications of occupational accidents $\left({ }^{* * * *} n \_02^{*}\right.$ posic_1 ${ }^{\star}$ uni_2) 
(...) I instruct health professionals on how to fill out the individual injury notification report $\left({ }^{* * * * *} n \_36^{*}\right.$ posic_1*uni_2)

(...) I orient the health team about the use of lab coats, protection equipment, products that can bring some damage to health $\left({ }^{* * * *} \mathrm{n} \_32^{*}\right.$ posic_1*uni_2)

From the relationship between instruments, objects, and work actions of RENAST nurses emerges the possibility of a deeper understanding of the articulation of these professionals. This occurs through home visits and guidance to workers, in order to support the collection or confirmation of data that enable the transformation and effectiveness of the work object, that is, the notification of occupational accidents.

It is revealed, from the aforementioned relationship, that training, and lectures are the nurses' main work tools. The use of these instruments is linked to information from home visits, orientations, and occupational accident notifications. Therefore, it is possible to interpret that the actions and the object of work guide the working tools used by the RENAST nurses.

\section{DISCUSSION}

In this study, it was possible to verify some characteristics of the nurses who make up the RENAST workforce in the Western Border, Macro South and Central regions of Rio Grande do Sul, Brazil. Characteristics such as those related to the gender of the participants allow us to visualize a mostly female performance. Such performance corroborates studies that report the historical and current feminization in nursing work ${ }^{15}$.

The fact that only eight of the 43 nurses had training in occupational nursing allows us to reflect on the need for politicalfinancial investment in relation to professional training in SUS, in the specificity of occupational health ${ }^{16}$. In addition, the absence of specialized training has repercussions on the health care provided to the working population. This occurs due to the difficulty in identifying and intervening, in a qualified way, in the relationship between health, work, and disease ${ }^{17}$.

Only five of the interviewed nurses are exclusively dedicated to occupational health, all of them work at CEREST. This result allows us to evaluate the performance of these professionals from two perspectives: the first demonstrates the focus of the CEREST nurses on workers' health, which is in line with the premises of the service ${ }^{7}$. The second reminds us of the work overload of nurses who develop and are responsible for numerous activities, which, besides causing damage to health, interfere negatively in the development of their work process ${ }^{18}$.

Regarding the work process of the RENAST nurses, it was possible to verify an organization consistent with the area of occupational health, which shows that nurses represent a workforce of relevance in the attention to it. This relevance is justified by the fact that these professionals work in the front line of preventive and curative health care ${ }^{19}$.

The importance of nurses' work in occupational health has been identified in other studies that show their performance in educational actions focused on workers ${ }^{20}$; health; management and development of actions to promote and protect occupational health ${ }^{21,22}$ and direct care for workers, according to the needs presented by them ${ }^{23}$.

Health promotion and protection actions are the focus of public policies for occupational health, which emphasize the preventive character rather than the curative ${ }^{9}$. This highlight corroborates the results of the category purpose and object of work of RENAST nurses, since they refer that the operationalization of nurses' work is performed in order to promote and protect the health of the working population and improve health care within the SUS.

Also in the aforementioned category, the worker is identified as the object of work of the investigated nurses. This result diverges from the conception that care is the object of nursing work ${ }^{24}$, which occurs due to the understanding that care is the work action developed by nurses ${ }^{25}$.

The environment and occupational accidents also verified as objects of nurses' work allow us to affirm how broad is the work of these professionals. This amplitude is evidenced by the responsibility in the transformation of environments and occupational accidents. Such transformation, in order to occur, depends on the investment of nurses in the performance of surveillance actions, health promotion and protection in the workplace ${ }^{22}$, as well as actions aimed at the identification of epidemiological data in relation to accidents at work ${ }^{26}$.

The relationship between nurses' purpose and object of work is imbricated in the attempt to achieve comprehensive health care for workers, within the scope of the SUS, through health promotion and protection actions that change the scenario where workers' labor practices are developed. The attempt to achieve comprehensive health care for workers, under this perspective, is identified in other studies that also highlight the focus on health promotion and protection actions ${ }^{7,9}$.

The work actions of the nurses in this study stand out for the execution of home visits and orientation. The former provides monitoring and evaluation of the users' health. This report demonstrates that the home visit, in the specificity of the workers' health care, is performed in order to meet existing health needs, corroborating the study that points out that the home visit has this objective ${ }^{27}$. In addition, it is understood that there is a strong articulation between RENAST nurses and primary health care, since home visits are conducted in this setting.

Regarding orientations, it is identified that they are carried out for workers in general and for health professionals who make up the RENAST. The guidance action helps in the process of 
understanding the relationship between health, work, and disease and, consequently, contributes to the implementation of interventions aimed at meeting the demands of this relationship ${ }^{28}$. Therefore, the guidance given by RENAST nurses can help in the process of qualification of the health care provided to workers. In order to support the aforementioned work actions, the nurses use training courses and lectures as working tools. The use of such instruments demonstrates the educative role of nursing and the incorporation of an educational process as an instrumental working action of these professionals ${ }^{29}$.

It is also noteworthy that the notification of occupational accidents was identified in this study as a work object of nurses. They are of utmost importance for the workers' health, since, from the data coming from these notifications, it is possible to elaborate intervention strategies that will constitute tools for the work ${ }^{26}$.

The relationship between actions, instruments and the object of work of nurses visualized in the second category focuses on direct care to workers and the production of epidemiological data. Such focus contributes directly to the provision of comprehensive health care to the working class 9 .

The results of this research allow us to (re)affirm that the nurses' work process is structured in order to comply with the guidelines of public policies on worker health, which highlight the actions of surveillance, promotion, and protection of health. However, it is understood that the professional practice of RENAST nurses is broad and complex. And that the work process of these professionals contributes directly to the qualification and strengthening of this network.

It was also identified that the work process of nurses is guided by the health demands of workers. And that the purpose, the object, and the work instruments have a strong relationship, that is, they are jointly organized to support the work actions of these professionals, transform the object of work and achieve the purpose of the work developed.

Regarding the object of work of the participants of this study, it is possible to observe a greater focus on the worker already suffering from work-related diseases. This focus is confirmed since work-related accidents and notifications of work-related accidents correspond to the main objects of nurses' work. It is also verified that the nurses' work tools have educational potential and are used to achieve improvements in workers' health and, consequently, in the services provided to the working population within the scope of the SUS.

Therefore, occupational health is recognized as a public health area, RENAST involves all the health services that constitute SUS, CEREST are key players in the strengthening of occupational health, and nurses, due to their skills and competencies, are an indispensable workforce for the qualification of this health area.

\section{REFERENCES}

1. Gomez CM, Vasconcellos LCF, Machado JMHM. Saúde do trabalhador: aspectos históricos, avanços e desafios no Sistema Único de Saúde. Cien Saude Coletiva. 2018;23(6):1963-70. https://doi.org/10.1590/1413-81232018236.04922018

2. Vasconcellos LCF. Vigilância em Saúde do Trabalhador: decálogo para uma tomada de posição. Rev Bras Saude Ocup. 2018;43(supl 1):e1s. http://dx.doi.org/10.1590/2317-6369000029517

3. Garbina AC, Pintor EAS. Estratégias de intra e intersetorialidade para transversalizar a saúde do trabalhador em todos os níveis de atenção à saúde. Rev Bras Saude Ocup. 2019;44:e18. http://dx.doi.org/10.1590/2317-6369000030118

4. Rosa LS, Cardoso LS, Costa VZ, Camponogara S, Busanello J, Cezar-Vaz MR. Rede de saúde do trabalhador: planejamento e execução do processo de trabalho. J Nurs Health. 2016;6(1):103-15. http://dx.doi.org/10.15210/jonah.v6i1.6038

5. Souza KMJ, Seixas CT, David HMSL, Costa AQ. Contributions of Public Health to nursing practice. Rev Bras Enferm. 2017;70(3):543-9.

https://doi.org/10.1590/0034-7167-2016-0401

6. Mattos RCOC, Castro HA, Cavalcante ALM, Dias E. Formação profissional como ação estratégica para implementação da Política Nacional de Saúde do Trabalhador e da Trabalhadora. Rev Bras Saude Ocup. 2019;44:e24. http://dx.doi.org/10.1590/2317-63690000015218

7. Cardoso LS, Cezar-Vaz MR. Elementos del proceso en el trabajo de la red de salud del trabajador. Index Enferm. 2018;27(4):196-200.
8. Jackson Filho JM, Garcia EG, David HG, Duracenko SRC, Simonelli AP. Acidentes de trabalho e atuação do Centro de Referência em Saúde do Trabalhador nas páginas do Jornal de Piracicaba entre 2007 e 2014. Interface (Botucatu). 2019;23:e180659. https://doi.org/10.1590/Interface.180659

9. Lacaz FAC. Continuam a adoecer e morrer os trabalhadores: as relações, entraves e desafios para o campo Saúde do Trabalhador. Rev Bras Saúde Ocup. 2016;41:e13. https://doi.org/10.1590/2317-6369000120415

10. Marx K. O capital: crítica da economia política. 32 ed. Rio de Janeiro: Civilização Brasileira, 2014

11. Fernandes MC, Souza NVDO, Mafra IF, D'Oliveira CAFB, Pires AS, Costa CCP. The content of occupational health and teaching methods in nursing education. Esc Anna Nery. 2016;20(3):e20160074. https://doi.org/10.5935/1414-8145.20160074

12. Camargo BV, Justo AM. IRAMUTEQ: um software gratuito para análise de dados textuais. Temas Psicol. 2013;21(2):513-8. http://dx.doi.org/10.9788/TP2013.2-16

13. Minayo MCS. O desafio do conhecimento científico: pesquisa qualitativa em saúde. 14 ed. São Paulo: Hucitec, 2014.

14. Brasil. Ministério da Saúde. Conselho Nacional de Saúde. Resolução $n^{\circ} 466$, de 12 de dezembro de 2012. Dispõe sobre pesquisa envolvendo seres humanos. Brasília: Ministério da Saúde, 2012.

15. Wadman M. Where are the women? Science. 2020;368(6486):21-5 https://doi.org/10.1126/science.368.6486.21 
16. Souza TS, Virgens LS. Saúde do trabalhador na Atenção Básica: interfaces e desafios. Rev Bras Saúde Ocup. 2013;38(128):292-301. https://doi.org/10.1590/S0303-76572013000200016

17. Silva TL, Dias EC, Pessoa VN, Fernandes LMM, Gomes EM. Occupational health in primary care: perceptions and practices in family health teams. Interface (Botucatu). 2014;18(49):273-87. https://doi.org/10.1590/1807-57622013.0227

18. Caballero JG. A study of occupational Health Nursing competencies and skills in Spain. Arc Prev Riesgos Labor. 2020;23(1):34-51.

19. Costa IP, Moreira DA, Brito MJM. Meanings of work: articulation with mechanisms of risk and protection for resilience. Texto Contexto Enferm. 2020;29:e20190085 https://doi.org/10.1590/1980-265x-tce-2019-0085

20. Roloff DIT, Cezar-Vaz MR, Bonow CA, Lautert L, Sant'Anna CF, Couto AM. Enfermeiros do trabalho: experiência interdisciplinar em saúde do trabalahador. Rev Bras Enferm. 2016;69(5):897-905. https://doi.org/10.1590/0034-7167-2015-0113

21. Farias AAR, Cardoso LS, Silva JJS, Sant'Anna CF, Lima JM, CezarVaz MR. The health of nursing professionals: reviewing health promotion strategies. J Res Fundam Care. 2019;11(3):828-35. http://dx.doi.org/10.9789/2175-5361.2019.v11i3.828-835

22. Mastroianni $\mathrm{K}$, Machles $\mathrm{D}$. What are consulting services worth? Applying cost analysis techniques to evaluate effectiveness. Workplace Health Saf. 2013;61(1):31-41. https://doi.org/10.1177/216507991306100105
23. Silva MA, Teixeira ER, Pereira ER, Silva RMCRA, Rocha RCNP, Rodon SOV. Saúde como direito e cuidado de si: concepção de profissionais de enfermagem. Rev Bras Enferm. 2019;72(1):159-65. https://doi.org/10.1590/0034-7167-2018-0066

24. Dias EG, Souza SPD, Gomes JP, Caldeira MB, Teixeita JAL. Riscos ergonômicos do ambiente de trabalho do enfermeiro na atenção básica e no pronto atendimento. J Nurs Health. 2020;10(2):e20102004. http://dx.doi.org/10.15210/jonah.v10i2.18036

25. Santos JAF, Ribeiro LVF. Emprego, estratificação e desigualdade. Estud Av. 2016;30(87):89-102. https://doi.org/10.1590/S0103-40142016.30870006

26. Ferreira MD, Pimeta FR, Facchin LT, Gir E, Canini SRMS. Subnotificação de aidentes biológicos pela enfermagem de um hospital universitário. Cienc Enferm. 2015;21(2):21-9. http://dx.doi.org/10.4067/S0717-95532015000200003

27. Joaquim FL, Camacho ACLF, Sabóia VM, Santos RC, Dos Santos LSF, Nogueira GA. Impact of home visits on the functional capacity of patients with venous ulcers. Rev Bras Enferm. 2016;69(3):439-7. https://doi.org/10.1590/0034-7167.2016690308i

28. Dias GL, Camponogara S, Costa VZ, Cezar-Vaz MR, Weiller TH, Cardoso LS. Representações sociais sobre saúde e meio ambiente para equipes de Estratégia Saúde da Família. Saúde Soc. 2018;27(1):163-74. https://doi.org/10.1590/s0104-12902018170658

29. Valero-Pacheco IC, Riaño-Casallas MI. Teletrabajo: gestión de la seguridade y salud em el trabajo em Colombia. Arch Prev Riesgos Labor. 2020;23(1):22-33.

https://doi.org/10.12961/aprl.2020.23.01.03 